DOI: $10.17805 /$ trudy.2018.5.7

\title{
МОДЕЛИРОВАНИЕ УЧЕБНОГО ПРОЦЕССА: ТЕХНОЛОГИИ РАБОТЫ С ОПРЕДЕЛЕНИЯМИ
}

\author{
В. П. Борисенко
}

Московский гуманитарный университет

\begin{abstract}
Аннотация: Представленный системный подход обучения технологиям работы с определениями (понятийный диктант, синквейн, письмо по кругу) позволяет реализовать педагогические задачи и обучить студентов навыкам формулирования определений. Впервые приведена авторская методика конструирования определений.
\end{abstract}

Ключевые слова: учебный процесс; понятийный диктант; педагогчческая задача; письмо по кругу

\section{MODELLING THE EDUCATIONAL PROCESS: TECHNIQUES OF WORK WITH DEFINITIONS}

\author{
V. P. Borisenko \\ Moscow University for the Humanities
}

Аннотация: The present system approach to teaching the techniques of work with definitions (conceptual dictation, cinquain, writing in circle) makes it possible to implement educational tasks and teach students the skills of phrasing definitions. For the first time the author presents his own method of constructing definitions.

Ключевые слова: educational process; conceptual dictation; pedagogical task; writing in circle

Современному студенту все труднее структурировать лавинообразно растущие и постоянно обновляющиеся объемы информации и знаний, следовательно, понимать и вписываться в условия новой экономики, что прямым образом отражается на образовательном процессе. Преподавателям все сложнее эффективно использовать старые методы образовательного процесса. Линейное чтение лекционного материала, традиционные проверки знаний студентов в виде семинарских занятий и экзаменов, не дают качественного понимания и усвоения материала.

Симбиотическая система «преподаватель - студент» функционирует односторонне, характерной чертой современного образовательного процесса стала слабая мотивация студентов. 
Таким образом, возникает необходимость в поиске новых системных подходов к образовательному процессу, одним из которых является применение различных технологий работы с определениями (понятийный диктант, синквейн, письмо по кругу) (Борисенко, 2017).

Понятийный диктант.

1. Учебные задачи: проведение первичного входного контроля; повышение эффективности образовательного процесса; вовлечение студентов в процесс познания; формирование умений и навыков построения определений специальных терминов; развитие репродуктивного и поискового уровня усвоения знаний студентов; оценка уровня подготовленности студентов.

2. Ожидаемые результаты: повышение эффективности познавательного процесса и качества результата обучения (практическая полезность); развитие научного интереса к процессу обучения; обучение процессу формулирования определений специальных терминов.

3. Форма выполнения: фронтальная — студенты одновременно выполняют одну и ту же работу.

4. Необходимые материалы: ручки, чистые листы бумаги, список понятий, видеопроектор, презентация.

5. Время: 30-40 минут.

6. Технология проведения занятия: студенты самостоятельно пишут определения по заданным преподавателям ключевым категориям (10-15 понятий, терминов) изучаемого курса; преподаватель оценивает понятийный диктант.

7. Вспомогательные материалы. Конструирование определений:

- первое ключевое слово: совокупность;

• определить: категория является процессом или объектом, предметом, явлением;

- подобрать ассоциативные связи и слова - синонимы;

- выделить существенных свойств (глаголы) («Посоветую вам никогда не определять наименование задачи именем существительным... сценические... задачи надо непременно определять глаголом» (Станиславский, 1954);

•указать отличительные особенности (дифференциальные свойства) (Сахарный, 1978);

- определить с какой целью или задачей существует данный процесс или явление (причина).

8. Варианты: другие ключевые категории лекции, семинарского занятия, курса, зарисовывание смысловой схемы (Борисенко, 2017) по рассматриваемой категории.

9. Результат: оцениваемый преподавателем понятийный диктант. 
10. Обсуждение, анализ, рефлексия. Каждому студенту предлагается ответить на вопрос «Что новое, важное и интересное Вы узнали?»

Конструирование определения с помощью синквейна.

1. Учебные задачи: активизация и стимулирование самостоятельной и творческой познавательной деятельности; вовлечение студентов в процесс обучения; обучение коллективному труду; повышение эффективности образовательного процесса; развитие репродуктивного, поискового и творческого уровня усвоения знаний студентов; формирование умений и навыков построения специальных терминов в форме пятистрочья; знакомить студентов с новыми технологиями и методами управления знаниями.

2. Ожидаемые результаты: закрепление ранее изученных и усвоение новых терминов, понятий; повышение эффективности познавательного процесса и качества результата обучения (практическая полезность); развитие научного интереса к процессу обучения; завершить давать определение понятий и специальных терминов в игровой форме; обучение процессу анализа и обобщения знаний о понятиях и специальных терминах.

3. Форма выполнения: групповая - работа выполняется группами по 3-4 человека.

4. Необходимые материалы: ручки, чистые листы бумаги, список понятий, видеопроектор, презентация, пример.

5. Время: 10-15 минут.

6. Источник.

Синквейн.

Слово происходит от французского «пять». Это стихотворение из пяти строк.

Первая строка - тема стихотворения, выраженная одним словом, обычно существительным.

Вторая строка - описание темы в двух словах, как правило, прилагательными.

Третья строка - описание действия в рамках данной темы тремя словами, обычно глаголами.

Четвертая строка - фраза из четырех слов, выражающая отношение автора к данной теме.

Пятая строка - одно слово, синоним к первому, эмоциональное, образное, философской обобщение, повторяющее суть темы.

Снквейны полезны ученику в качестве инструмента для синтезирования сложной информации. Учителю - в качестве среза оценки понятийного и словарного багажа учащихся. Синквейн резюмирует информацию, излагает сложные идеи, чувства и представления в нескольких словах.

Использовать синквейны можно при изучении любого предмета. 
Научные труды Московского гуманитарного университета 2018 № 5

1. Кто? Собака

2. Какая? Мохнатая, Большая

3. Что делает? Спит, Играет, Лает

4. Предложение. Мне нравится играть с собакой

5. Ассоциация. Друг (Трифонова, 2002).

7. Технология проведения занятия - на экране демонстрируется презентация подготовки синквейна, студенты в группе придумывают, вспоминают и записывают пять строк по категориям изучаемой дисциплины (семинара): ным);

первая строчка - называют одним словом категорию (существитель-

2 - описывают категорию в двух словах (два прилагательных);

3 - представляют действия в рамках этой категории тремя словами;

4 - составляют фразу из четырех слов, показывающих отношение к категории;

5 - подбирают синоним из одного слова, повторяющий суть категории.

8. Вспомогательные материалы (презентация): правила для создания синквейна.

9. Результат: совместный выбор преподавателем и студентами лучшего синквейна.

10. Обсуждение, анализ, рефлексия. Каждому студенту предлагается ответить на вопрос «Что новое, важное и интересное Вы узнали?».

Письмо по кругу.

1. Учебные задачи: активизация и стимулирование самостоятельной и творческой познавательной деятельности; вовлечение студентов в процесс обучения; ознакомление студентов с новыми технологиями и методами управления знаниями; обучение коллективному труду; повышение эффективности образовательного процесса; развитие репродуктивного, поискового и творческого уровня усвоения знаний студентов; формирование умений и коллективных навыков построения определений специальных терминов.

2. Ожидаемые результаты: обучение процессу формулирования определений специальных терминов в игровой форме; закрепление ранее изученных и усвоение новых терминов, понятий; обучение процессу анализа и обобщения знаний о понятиях и специальных терминах; повышение эффективности познавательного процесса и качества результата обучения (практическая полезность); развитие научного интереса к процессу обучения.

3. Форма выполнения: групповая - работа выполняется группами по 3-4 человека.

4. Необходимые материалы: ручки, чистые листы бумаги, секундомер, список понятий, пример. 
5. Время: 10-15 минут.

6. Технология проведения занятия:

- каждый студент на своем листке самостоятельно пишет определение по заданной преподавателем одной для всех категории в течении одной минуты;

- по сигналу секундомера каждый передает свой листок по часовой стрелке, читает чужое определение и дополняет, расширяет, углубляет его своими мыслями;

-через одну минуту по сигналу секундомера передает листок дальше по часовой стрелке, пока все члены группы не примут участие в написании текста;

• затем в группе выбирают лучшее определение и зачитывают его всей аудитории.

1. Источник.

Творческая работа редколлегии журналов - по воспоминаниям И. Л. Андроникова. «Я начинал работать в “Чиже” и “Еже" - в журналах, которые были созданы по инициативе Маршака. Но к тому времени, когда я поступил в издательство, Маршак руководил не “Ежом" и не “Чижом”, а был уже, так сказать, ментором всей ленинградской детской литературы. Когда он приезжал в редакцию - все расступалось. “Маршак приехал!” - все торопились к нему с рукописями, с рисунками, с вопросами. Он был как бы главный редактор. А в “Еже” и в “Чиже” было очень славно. Он туда только иногда заходил. Как-то не совсем довольно посматривал, как его продолжатели и ученики Евгений Шварц, Николай Заболоцкий, Николай Олейников ведут это дело. Говорил, что журнал теряет своеобразие. На самом деле журнал был великолепный. Мне казалось, что происходит какая-то ошибка, что я получаю зарплату вместо того, чтобы платить за то, что я работаю в “Еже” и “Чиже”. Это было одно удовольствие. В 12 часов являлись все члены редколлегии, садились вокруг стола, который занимал почти всю комнату, и уславливались, на какую тему будут писать. Каждый, закрывая рукой, писал свое, хохотал, писал, потом бросал это направо. Слева получал лист, хохотал еще громче, прибавлял свое, бросал направо, слева получал лист... Когда все листы обходили стол, читали все варианты, умирали со смеху, выбирали лучший вариант, и все начинали его обрабатывать. Придут художники, оставят картинки - и остаются. Придут поэты, оставят стихи - и тоже остаются. Вот уже окончен рабочий день, в коридорах темнота, а у нас свет, хохот и словно праздник. Журнал выходил всегда вовремя и был интересный. На него кидались и дети, и взрослые» (Андроников, 1981: 62-63).

2. Результат: совместный выбор преподавателем и студентами лучшего определения. 
3. Обсуждение, анализ, рефлексия. Каждому студенту предлагается ответить на вопрос «Что новое, важное и интересное Вы узнали?».

Представленный системный подход обучения технологиям работы с определениями, позволяет реализовать педагогические задачи и обучить студентов навыкам формулирования определений. Применение данного подхода позволяет воспитывать «активного студента», слушающего, слышащего, понимающего и реализующего полученную информацию (Борисенко, 2007) в виде знаний, умений и навыков, что является главной целью образовательного процесса.

\section{СПИСОК ЛИТЕРАТУРЫ}

Андроников, И. А. (1981) А теперь об этом : сборник. М. : Советский писатель. 448 с.

Борисенко, В. П. (2007) Управление знаниями в современных условиях // «Высшее образование для XXI века» IV Международная конференция. Москва, 18-20 окт. 2007 г.: Доклады и материалы. Секция. Педагогика и образование. Вып. 2. М. : Изд-во Моск. гуманит. цн-та. С. 84-87.

Борисенко, В. П. (2017) Интерактивные и творческие методы в организации учебного процесса. М. : Изд-во Моск. гуманит. ун-та. 82 с.

Сахарный, Л. В. (1978) Как устроен наш язык. Книга для учащихся старших классов. М. : Просвещение. 160 с.

Станиславский, К. С. (1954) Собрание сочинений : в 8 т. М. : Искусство. Т. 2. $421 \mathrm{c}$.

Трифонова, Е. А. (2002) Развитие критического мышления (учебное пособие-хрестоматия) // Учитель и ученик : возможность диалога и понимания. Развитие критического мышления (Базовая модель). Кн. 2 : Развитие критического мышления (учебное пособие-хрестоматия). Сост. Е. А. Генике, Е. А. Трифонова. М. : Бонфи. 238 с.

Дата поступления: 15.08.2018 г.

Борисенко Виталий Павлович - кандидат экономических наук, доцент, профессор кафедры менеджмента Московского гуманитарного университета. Адрес: 111395, Россия, г. Москва, ул. Юности, д. 5. Тел.: +7 (499) 375-28-54. Эл. адрес: vpbprof@mail.ru

Borisenko Vitaliy Pavlovich, Candidate of Economics, Associate Professor, Professor, Department of Management, Moscow University for the Humanities. Postal address: 5, Yunosti St., Moscow, Russian Federation, 111395. Tel.: +7 (499) 375-28-54. E-mail: vpbprof@mail.ru 


\section{Для цитирования:}

Борисенко В. П. Моделирование учебного процесса: технологии работы с определениями [Электронный ресурс] // Научные труды Московского гуманитарного университета. 2018. № 5. URL: http://journals.mosgu.ru/trudy/ article/view/827 (дата обращения: дд.мм.гг.). DOI: 10.17805/trudy.2018.5.7 